\title{
A Journey in Magic and Realism Performing the Role of Titania from William Shakespeare's "A Midsummer Night's Dream"
}

\author{
Mya Brown
}

Follow this and additional works at: https://researchrepository.wvu.edu/etd

\section{Recommended Citation}

Brown, Mya, "A Journey in Magic and Realism Performing the Role of Titania from William Shakespeare's "A Midsummer Night's Dream"' (2015). Graduate Theses, Dissertations, and Problem Reports. 5267. https://researchrepository.wvu.edu/etd/5267

This Thesis is protected by copyright and/or related rights. It has been brought to you by the The Research Repository @ WVU with permission from the rights-holder(s). You are free to use this Thesis in any way that is permitted by the copyright and related rights legislation that applies to your use. For other uses you must obtain permission from the rights-holder(s) directly, unless additional rights are indicated by a Creative Commons license in the record and/ or on the work itself. This Thesis has been accepted for inclusion in WVU Graduate Theses, Dissertations, and Problem Reports collection by an authorized administrator of The Research Repository @ WVU. For more information, please contact researchrepository@mail.wvu.edu. 


\title{
A Journey in Magic and Realism
}

\author{
Performing the Role of Titania from William \\ Shakespeare's "A Midsummer Night's Dream"
}

\author{
Mya Brown
}

\author{
Thesis submitted to the College of Creative Arts at \\ West Virginia University \\ in partial fulfillment of the requirements for the degree of \\ Master of Fine Arts \\ In \\ Theatre \\ Jerry McGonigle, M.F.A., Chair \\ Jessica Morgan Bishop, M.F.A \\ Andrea Washington-Brown, M.F.A \\ Department of Theatre and Dance
}

Morgantown, West Virginia

2015

Keywords: acting techniques, Constantine Stanislavski, Sanford Meisner, Uta Hagen, psychological manipulation 


\begin{abstract}
A Journey in Magic and Realism:

Performing the Role of Titania from William Shakespeare's,

A Midsummer Night's Dream

Mya Brown
\end{abstract}

This document consists of a detailed account of my process in developing my thesis role and the pedagogical experiences which have contributed to my artistry. The purpose of this thesis role was to allow exploration of the character Titania, from William Shakespeare's $A$ Midsummer Night's Dream. Titania was an interesting character to portray due to the fact that I had previously performed this role. My study consisted of applying acting methodology to Shakespeare's play in order to realistically present a fresh characterization of the role. A detailed interpretation of the text along with the engagement of my imagination provided the given circumstances essential to developing the role. The results revealed my potential to create a complex character within the world of magic and realism. 


\section{Acknowledgements}

I would like to thank the inspiring and amazing people who have contributed to my growth and development as an artist at West Virginia University including:

Jerry McGonigle, who is the glue that makes sense of the nonsensical and supports with every fiber of his being. One of the best directors I have ever had the pleasure to work with;

Lee Blair, who believes in you even when you doubt yourself. I am indebted to him for reintroducing me to my love of music and singing;

Jessica Morgan, who helps you to remain grounded and rooted among all of the chaos;

Laura Hitt, who was my rock through some major adversity and who taught me the importance of being good to my facility (body, mind, and spirit);

And my beautiful, supportive, and loving family, who put up with my absence, mood swings, and belting in the shower. Without the love and support of my husband and children, I would not be the confident artist I am. 


\section{Table of Contents}

Abstract 


\section{Table of Figures}

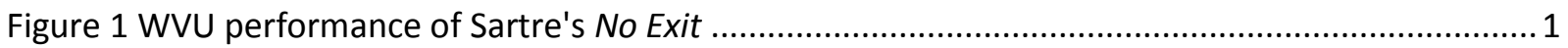

Figure 2 WVU Performance with Theseus (Nick Ryan) and Hippolyta (Brianne Taylor) ....................... 3

Figure 3 WVU performance Oberon (Kyle Walters), Titania (Mya Brown), and Puck (Isaac Snyder). .... 4

Figure 4 WVU performance Hermia (Shannon Uphold) and Lysander (Landon Green)........................ 6

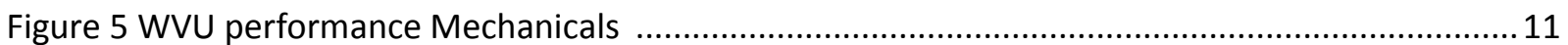

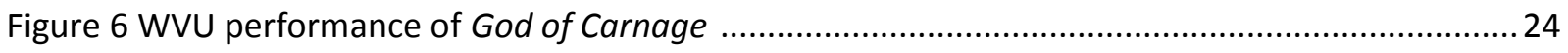

Figure 7 WVU performance Set design \& Lighting design ...........................................................26 


\section{Introduction}

I began my career at West Virginia University (WVU) full of excitement and anticipation. As an actor I appreciate the demand for my professional growth which has been cultivated by the outstanding faculty at WVU. I am impressed by the faculty's ability to support their individual class objectives with that of the whole program and by the clear line of communication and collaboration amongst them. As academia is my future career objective, I have obtained the necessary tools to make my dreams a reality. The faculty and degree program at WVU have allowed me to build upon my own stage experience and expand my knowledge of

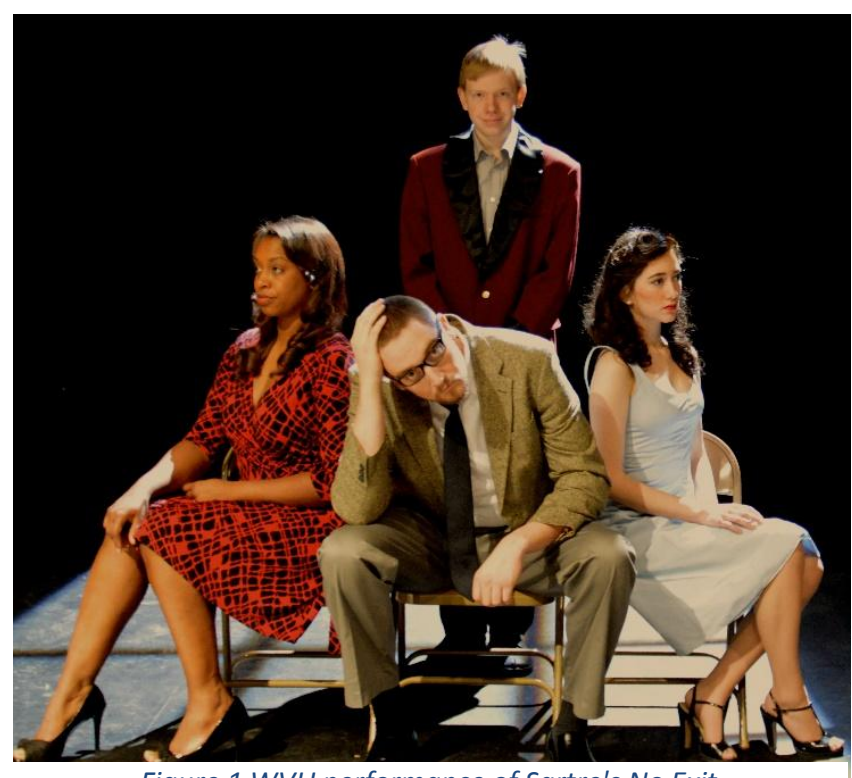

Figure 1 WVU performance of Sartre's No Exit

Theater. During my time at WVU, I have had the fortune to perform in several challenging and satisfying roles. I have had the honor to perform in works from William Shakespeare, Yasmina Reza, John Paul Sartre and several other inspiring playwrights. The experiences I've had and connections I've made will aid in my end goal of sharing with others in order to inspire and cultivate their talents.

One of the most valuable lessons I have recently learned during my time at WVU was that there is a direct connection between an actor's ability to use their imagination to live in a different world and their being susceptible to mental illnesses. My research of this topic, 
included a closer look at the idea of acting being a dangerous game. Actors make themselves so vulnerable to psychological manipulation through their imagination that there must be a heightened sense of consciousness by all who contribute to creating. We have a responsibility to the stage to keep an open line of communication within the theater community so as to promote respect and honor of the craft.

The most anticipated performance of my career thus far was my thesis role of Titania the Queen of the Fairies from William Shakespeare's, A Midsummer Night's Dream. This was my fourth performance of the play; I have previously played the roles of Puck, Hippolyta, and Titania with other theatre companies. WVU's performance was held in the Gladys G. Davis Theatre in November and December of 2014. Upon my initial receipt of the role, anxiety and excitement overwhelmed me. I was flooded with ideas and questions concerning the role, mostly prompted by my previous performance of it. How could I approach the role from a fresh perspective? Will echoes of my previous performance hinder this production? All in all I was eager to start another journey into the world of the play.

After the first reading of the script, new themes revealed themselves such as dominance, desire, and true love. During my process I learned how to use my voice, my movement, and the text to aid in my truthfully living on stage. Three imperative tools to developing my thesis role included fully understanding the text, fully embodying the inner and outer state of Titania, and finally immersing myself within the world of the play. 


\section{Plot Synopsis}

Shakespeare intertwines four different storylines in his comedy A Midsummer Night's

Dream. Exploration of marriage, courtship, and lust are displayed in the differing plots.

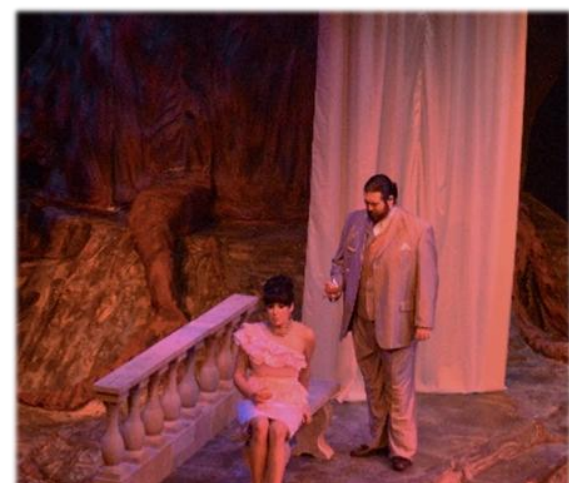

Figure 2 WVU Performance with Theseus (Nick Ryan) and Hippolyta (Brianne Taylor)
The play starts with a revealing scene between

Theseus and Hippolyta; right away the audience is confronted with the differing roles of men and women in society. Theseus and Hippolyta are to be wed but their beginnings have been rocky: he conquered her tribe and took her as his bride. Theseus declares, "I wooed thee with

my sword, and won thy love doing thee injuries, But I will wed thee in another key, with pomp, with triumph, and with reveling." (Shakespeare 3-4)

Enter the young lovers, Hermia and Lysander, who are defending their right to love each other to Egeus, Hermia's father. Egeus has other plans for his prized possession: Hermia is to marry Demetrius. While these characters plead their respective cases to Duke Theseus, it is revealed that Demetrius has already gained the love of a fair lady, Helena. To avoid choosing between marrying Demetrius or living out her days as a nun, Hermia takes Lysander up on his offer to run away with him. Before they leave the star-crossed lovers reveal their plans to Hermia's best friend Helena; Helena in turn exposes Hermia and Lysander's plans to Demetrius. All four of the young eager lovers find themselves lost in the woods on their journey to secure their love and stand up for their beliefs. 
While in the woods Shakespeare's final

storyline unfolds. Titania and Oberon, Queen

and King of the fairies, are in the throes of a

heated debate which is causing chaos in nature.

Oberon is insistent upon having Titania's

changeling boy as his own, but the Queen will

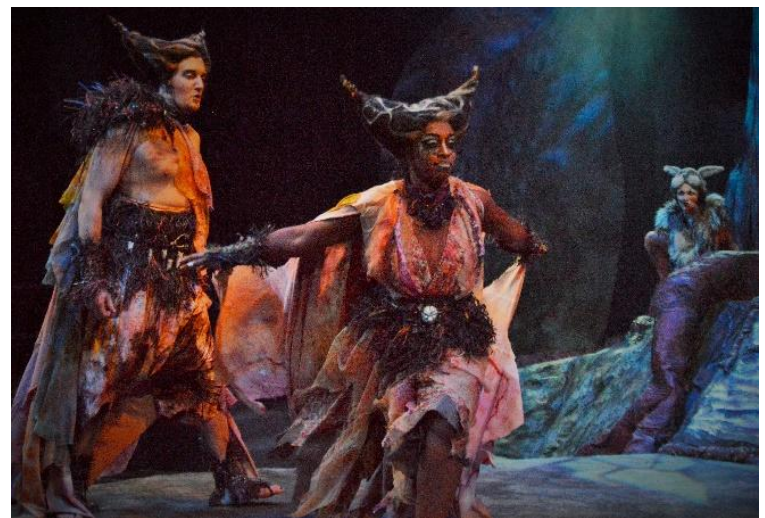

Figure 3 WVU performance Oberon (Kyle Walters), Titania (Mya Brown), and Puck (Isaac Snyder).

not concede. Oberon plots with his servant

Robin Goodfellow, also known as Puck, to cast a spell over the fairy Queen, diverting her attention from the boy to a hideous lover. While Titania is under the spell Oberon takes the boy. Oberon, waiting for his servant to return, comes upon a pair of hopeless youths: Helena, madly in love, and Demetrius, who wants nothing to do with her. Oberon decides to help the beauty by having his servant cast a love spell on Demetrius so he will fall in love with her. Unfortunately, Puck makes a mistake and the four Athenian lovers are consumed with new love, jealousy, and bickering.

Meanwhile, Shakespeare introduces a group of clowns to the play, craftsman brought together to perform a play for Duke Theseus on his wedding day. This "crew of patches, rude mechanicals," (Shakespeare 41) is a clever device used by Shakespeare to infuse the play with slapstick commedia style antics. The leader of this rag tag gang, Nick Bottom, is targeted as a conduit for Oberon's evil plan to entrap Titania. In the end, however, the lovers are happily reunited, Theseus and Hippolyta are merrily wed, the mechanicals perform a magnificent play, and nature is restored when the fairies settle their differences and reinstate peace. 


\section{Analysis}

When approaching the text I began with an action analysis of the entire script and then a separate action analysis of my thesis role. The action analysis consisted of a breakdown of action within the play from scene to scene focusing on the main action of each scene. The study was to establish main points of action, and then use that information to identify themes, given circumstances, and plot points. From the action analysis it was obvious that Shakespeare's themes within the play included the influence of status, love/relationships, and the power dynamic between men and women.

From the beginning of the play status is addressed. Theseus wields his status as a Duke over the Amazons, as well as the people of Athens. This theme is addressed in the first scene when Egeus pleads his case concerning his daughter to the Duke. Theseus has the power to decide the young girl's fate, "either to die the death or abjure forever the society of men..." (Shakespeare 5) This theme of status was paralleled in the fairies storyline. Titania and Oberon rule nature and are the father and mother of the changing seasons. Due to the animosity between them, the seasons become confused and it overwhelms nature:

"The spring, the summer, the childing autumn, angry winter change their wonted liveries; and the mazed world by their increase knows not which is which. And this same progeny of evils comes from our debate, from our dissension; we are their parents and original." (Shakespeare 21)

Oberon lords his power and status over his servant Puck, mocking and abusing him as he demands Pucks loyalty and service. Titania easily establishes her status over her train of fairies, 
but, unlike Oberon, cherishes her servants and treats them as generously as she would her children. Shakespeare uses the societal relationships of people in Athens to highlight the differences between the royals and the nobles; although both groups are of the upper class, there is still a marked distinction amongst them. The mechanicals, as working class citizens, are yet another example of the class demarcation amongst the people of the city.

There is a great deal of coupling in the play: Hermia and Lysander, Helena and Demetrius, Hippolyta and Theseus, Titania and Bottom, Titania and Oberon, and (the no less significant) Bottom and the mechanicals. Through these relationships the audience is clued in to Shakespeare's outlook on love/relationships and the power dynamic between males and females.

In the beginning of the play the female characters represent a combination of strength, defiance, and desire. Hermia displays her strength when she defies her father due to her desire for Lysander. Helena shows her strength when she defies

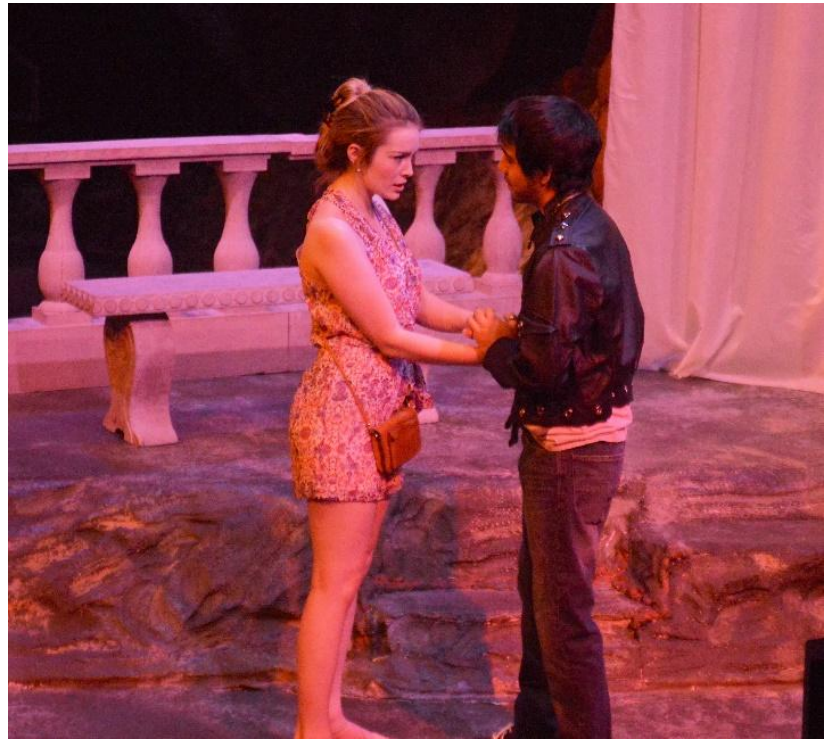

Figure 4 WVU performance Hermia (Shannon Uphold) and Lysander (Landon Green)

Hermia by deciding to tell Demetrius of Hermia's and Lysander's flight from justice. Titania uses her power to defy Oberon when she denies him the changeling boy in her possession. Even Hippolyta performs acts of defiance in Act I.I of the play. Though her actions seem minimal, Theseus notices the unhappiness in his soon to be bride and asks, "What cheer my love?" 
(Shakespeare 7) Outside forces change each of these ladies' fate: Lysander falls out of love with Hermia, Demetrius falls in love with Helena, and Titania is overcome with affection for an ass. The changes in these ladies' circumstances unveil an even greater strength than previously seen in the young lovers, Hermia and Helena. However, Titania is weakened by her new found situation. What is Shakespeare playing at by changing these females' circumstances? What is his lesson or statement concerning the female sex?

I had a difficult time accepting the outcome of the play for all of the female characters. Each of the women in the play took on a submissive role with respect to their male counterparts, and in some cases to their detriment. While Hermia and Helena receive their "happily ever after", Titania and Hippoltya are made to submit by force and against their free will. I found it especially hard to accept the fact that Shakespeare neglected to fully complete Titania and Oberon's plot. Instead, Shakespeare sums up the events leading to the King and Queen's reconciliation in Oberon's monologue in Act IV.I: "When I had at my pleasure taunted her, And she in mild terms begged my patience, I then did ask of her her changeling child; Which straight she gave me..." (Shakespeare 63) This summation seemed a lazy afterthought, and in the end I just accepted it but never grew to understand it. 


\section{Action Analysis}

Act 1 Scene 1: Hermia and Lysander decide to run away from Athens to pursue a life together away from the tyranny of Hermia's father.

Act 1 Scene 2: The mechanicals, led by Nick Bottom the weaver, decide to perform the play Pyramus and Thisby for Duke Theseus on his wedding day.

Act 2 Scene 1: Oberon plots to cast a spell over Titania making her vulnerable to his demands; he also decides to cast the same love spell on Demetrius so he will fall in love with Helena.

Act 2 Scene 2: Lysander, under a spell, falls in love with Helena and leaves Hermia.

Act 3 Scene 1: Titania falls in love with Bottom, whose head has been transformed by Puck into that of an ass.

Act 3 Scene 2: It is revealed that Puck has mistakenly made the wrong young lovers fall in love with each other, chaos ensues.

Act 4 Scene 1: Oberon releases Titania from the love spell and they reunite; he also has Puck remove the asses head from Bottom.

Act 4 Scene 2: Bottom is reunited with the other mechanicals and they leave to perform for the Duke.

Act 5 Scene 1: The mechanicals successfully perform for the Duke and Puck makes a final plea to the audience to "give me your hands, if we be friends". (Shakespeare) 


\section{Action Analysis for Titania}

Act 2 Scene 1: Titania refuses to give her changeling boy to Oberon.

Act 2 Scene 2: Titania sleeps in her bower and Oberon casts a love spell on her.

Act 3 Scene 1: Titania falls in love with Bottom.

Act 4 Scene 1: Titania is released from the love spell and reunites with Oberon.

Act 5 Scene 1: Titania, Oberon, and all of the fairies bless the newly united couples.

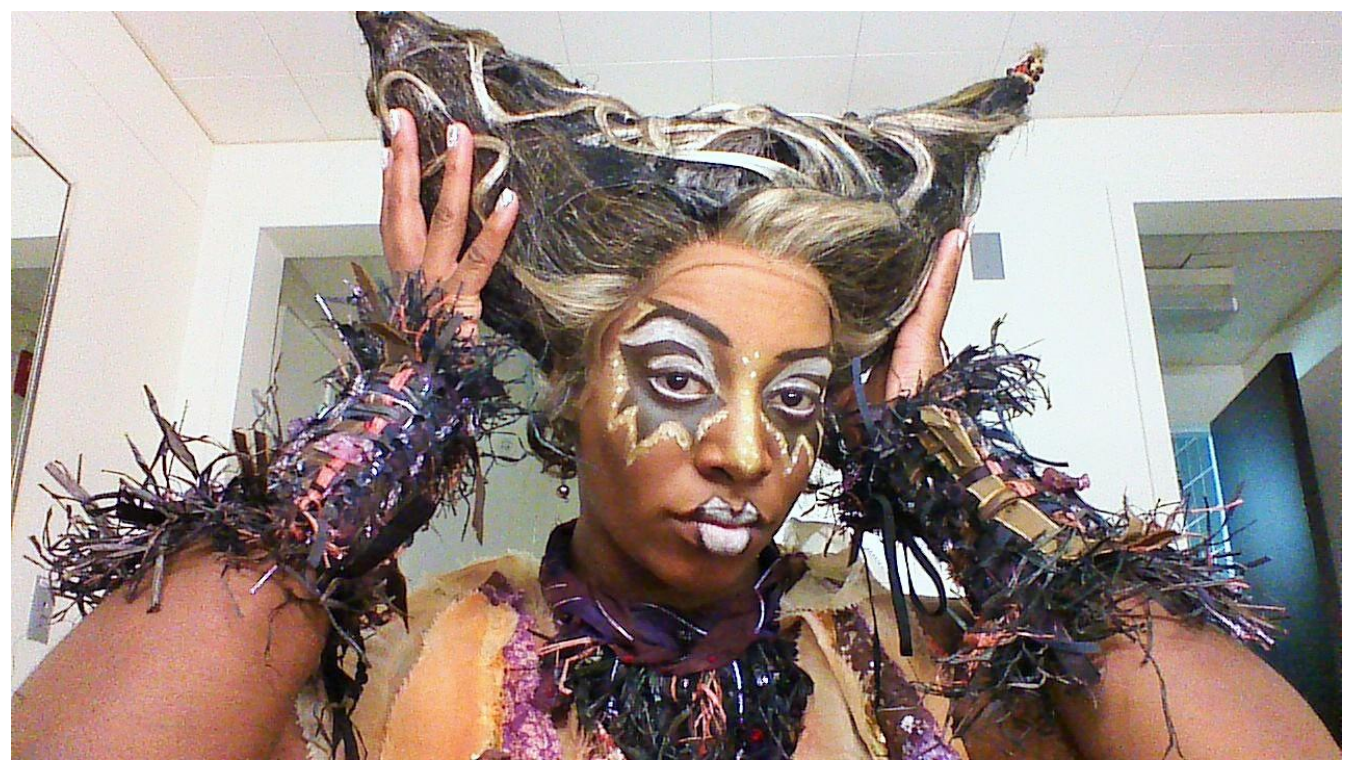

Figure 5 WVU performance Titania (Mya Brown) 


\section{Character Analysis}

\section{Basic Information}

Full name: Titania

Gender: Female

Species: Fairy

Age: Eternal

Native Language: The Queen's English

Relationship Status: Married

\section{Physical Appearance}

Height: 5'9'

Weight: 180lbs

Figure Build: Voluptuous

Hair Color: Dark Brown

Hairstyle: Crown of Hair shaped like horns

Eye Color: Brown

Skin Color: Brown

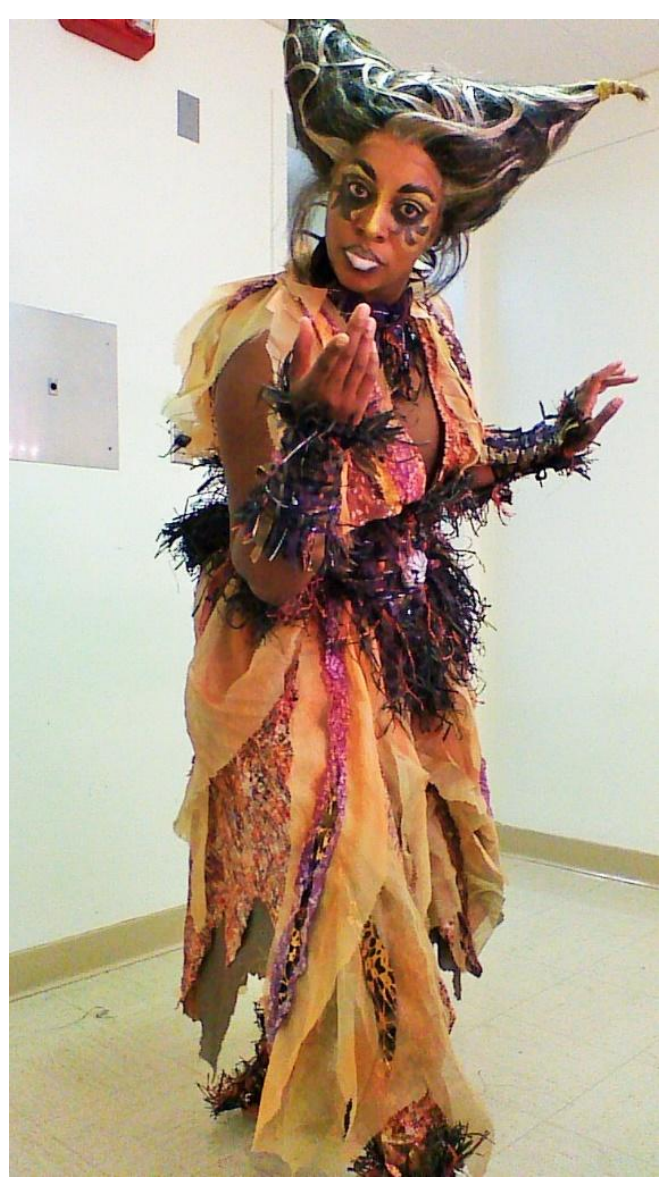

Figure 6 WVU performance Titania (Mya Brown)

\section{Personality}

Personality: Proud and commanding presence

Likes: Dancing, Singing, Love-making

Dislikes: Confinement, submission

Fears: Losing her husband 


\section{Concept}

At the first rehearsal, the director introduced the cast to each other, to the text (table read), and to his overall concept for the production. He explained that his overall goal was to honor the text first, and that in doing so the comedy would come. He stated that the time period was not specific, "It's today I guess." The location was also ambiguous and the technical elements, including costuming, lighting, and set design, were a reflection of this concept. The director stated that there would be no cultural statements.

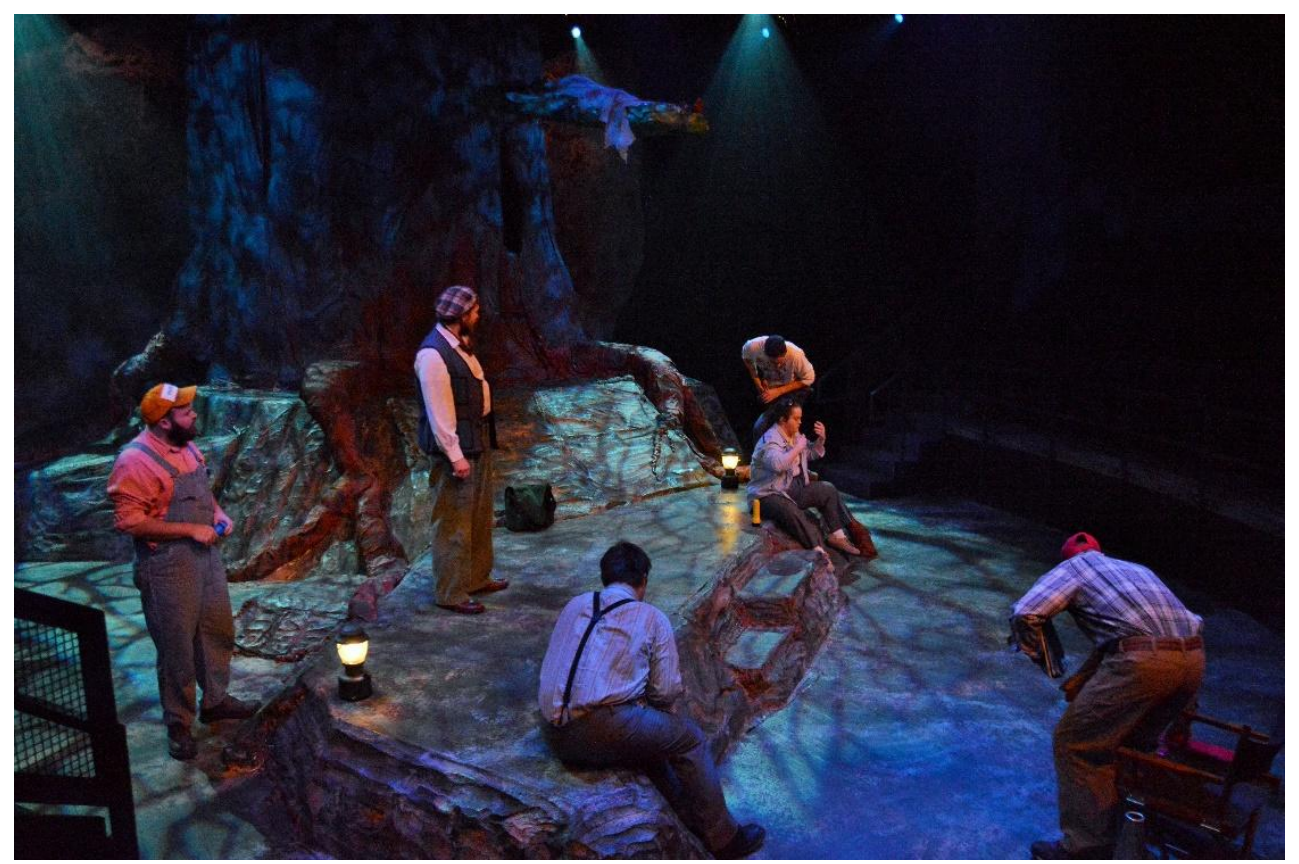

Figure 7 WVU performance Mechanicals 


\section{Research}

\section{William Shakespeare}

There is no record of William Shakespeare's birth. Scholars have deduced that

Shakespeare's birthday was probably April 23, 1564 based on records confirming his baptism on April 26, 1564 at Holy Trinity Church in Stratford-upon-Avon. He lived to be fifty-two years old, dying in 1616. He was born to a leather merchant, John Shakespeare. Before his son's birth, John Shakespeare rose to the positions of alderman and bailiff. William's mother was Mary Arden, a local heiress. Late November of 1582, Shakespeare married Anne Hathaway and they conceived three children before the infamous "lost years," the seven year period which is unaccounted for in Shakespeare's life.

Though education was extremely important during Shakespeare's time, there are no records of his educational background. However, scholars believe he attended King's New School in Stratford as a young man. The curriculum covered reading, writing, and the Classics, which might account for Shakespeare's love of the Classics. In the 1590's, Shakespeare was known as a managing partner of the Lord Chamberlain's Men where he was thought to have started as an actor in the theatrical company. He also contributed to the group by directing and playwriting. His early works consisted mostly of histories; some examples include Richard II, Henry VI parts 1-3, and Henry V. However, Shakespeare is credited with writing several comedies before 1600 as well, such as A Midsummer Night's Dream, and Much Ado About Nothing. There is no concrete account of the first production of A Midsummer Night's Dream, but it is believed to have first appeared in print in 1600. During the latter part of his career Shakespeare contributed to theatre with some great tragedies, such as Hamlet, King Lear, and 
Othello. Shakespeare wrote mostly in blank verse but often combined the style with poetry or prose. While his style of writing was mostly conventional, he adapted the style to allow for a freer flow or rhythm of the lines; this fact is evident in A Midsummer Night's Dream.

\section{Acting, a Dangerous Game}

I believe that acting can be a dangerous game; however, my experiences with the rehearsal and production process for A Midsummer Night's Dream were never scary or dangerous. I grew as an actor and was able to better articulate what acting is, as a result of my time working on the play. Sanford Meisner defines acting as "Living truthfully under imaginary circumstances" (Meisner 15). Constantine Stanislavski asks actors to use their imaginations to live within the world of a play; this begins with the Magic "If" (Merlin 127-130). I believe that acting is the ability to convey another person's point of view and live their story in front of observers for the purpose of entertaining, educating, inspiring, and/or inciting action. These definitions and tools for creating and living a performance are essential to an actor's success, but by doing this work actors make themselves vulnerable and expose themselves emotionally. Therefore, the actors as well as the other contributors (director, fellow actors, etc.) have a duty to take care when developing the artistry of theatre. Our art demands that we become someone else, subscribe to their truthful point of view for the two and a half hours, give or take, per performance that we live as them. How strong must the mind be to absorb that without any damage? Actors make themselves so vulnerable to psychological manipulation through imagination that there must be a heightened sense of consciousness by all who contribute to creating theatre. 
My experience with A Midsummer Night's Dream was a testament to the necessity of trust and respect needed between an actor and a director. Some directors take a hands-on approach to the rehearsal process and end up giving too much guidance; i.e., telling an actor when, where, and how to deliver a line or interact with others on stage. Some directors take a more organic approach to the work, which can be useful; however, there comes a time to give the work structure. I had the misfortune of working with a director who, from my experience, thought the most efficient approach to the work was to ridicule and mortify the actors into a performance. I guess he was trying to use some horrendous shock techniques, or possibly reverse psychology, to "inspire" his actors. For example, he would tell his actors things like: "I cast you as a lead, now act like one!" or "What the hell play are you doing?" He even went as far as to cry while he criticized the actors for not trusting each other or him. He then explained that due to this mistrust, the actors had not earned the right to use the text of the play. As an actor, notes such as these serve no purpose. There is no beneficial information an actor can use to make adjustments in order to better serve the play. Despite his intentions, these unscrupulous techniques led to a greater mistrust of the director and hindered the growth of the production. Above all, it caused great mental stress on some of the actors. His style created an atmosphere of fear, hatred, and trauma. As a result of this abusive approach to acting, several of the actors in the production had to seek outside counseling. Some of the actors suffered from severe mental issues that were exacerbated by their experience with this director. With counseling, and in some cases medication, the actors were able to successfully complete the process. Many actually had a good time once the show opened and the director was no longer lurking about. 
In contrast, working on A Midsummer Night's Dream was amazing! The director treated everyone with respect and dignity. Although he demanded a high level of commitment, trust among the ensemble, adherence to the text, and flexibility of interpretation, he created a safe environment in which to pursue these demands. As a result I was able to come to him with questions and concerns regarding my character. I felt valued and it made me want to work harder to help him realize his vision for the play.

There are several scientific studies comparing creative minds to those of psychologically disordered minds. None specifically address the impact of relationships in the work environment to the mental health of creative artists. However, several found a correlation between the creative mind and certain personality disorders; i.e., bipolar disorder, borderline personality disorder, and schizophrenia. Shelley H. Carson's study claims:

Because the disorders associated with creativity, as well as creativity itself, are both heritable and polygenetic, several investigators have suggested that creative thought processes may share genetic factors with such disorders...Such a shared vulnerability model explains numerous findings, including the greater risk of psychopathology found in some creative people... (Carson 145)

These findings call for an awareness in creative people in order to maintain a healthy mental facility. The awareness I suggest was naturally present during the rehearsal process for $A$ Midsummer Night's Dream. Actors were treated with respect and dignity, and as a result returned those qualities to the director. In the artistry of theatre appropriate behavior amongst 
peers becomes a gray area because the work we do requires an amount of physical and emotional touch, which is why we have a greater responsibility to take care of one another:

Creativity is a highly valued trait in fields as diverse as business, sports, and the military, as well as the arts and sciences. Despite the association of creativity with desirable personal features, the tendency for creative people to suffer from mental illness has been noted since the time of the Greeks. Plato, for example, suggested that poets, philosophers, and dramatists suffered from "Divine madness" while Aristotle was among the first to associate poets with melancholia. (Carson 145)

Carson suggests that creative people are more susceptible to mental illness, and this idea is as old as theatre itself. Acting is a dangerous game both physically and mentally, so it is necessary to be prepared and aware. 


\section{Rehearsal and Production}

While studying Shakespeare at WVU one of the most valuable lessons I learned was, "you must understand what you are saying." The director of A Midsummer Night's Dream is the author of that statement and he applied that idea to the rehearsal process. In a recent rehearsal process for a different Shakespearean play, a different director used an organic-, movement-, and ensemble-based style of approaching the text. In early rehearsals actors were encouraged to connect to their characters and scene partners through Viewpoints work, taking imaginative journeys and freely exploring contact improvisations. For some actors this style of working grounded them in their character's movement; however, once the actors were called upon to use the text, it was obvious that they didn't have an understanding of it. Due to the disconnect between what a character was actually saying and what the actor understood the character to be saying, there became a level of stress and frustration in rehearsals which hindered the process. Scenes had no objectives or consistency of action, lines were difficult for the actors to remember, and animosity started to fester among the ensemble. What started as a fun and open work environment quickly changed to one of confusion and dissension. The potential growth of the play was stifled by the circumstances surrounding the director and ensemble, and it can be largely attributed to the rehearsal approach. I believe the approach used during this rehearsal process have the potential to be effective, if combined with an attention to the text.

I was extremely excited to begin the rehearsal process for A Midsummer Night's Dream. It was my second opportunity to work with the director, and my previous experience was full of 
exhilaration and insight. Rehearsal began with a brief speech from the director detailing his approach to rehearsal and laying out his expectations for actors. A standout statement made by the director in reference to the play was, "It's a comedy but has a magical side and it is deeper than people give it credit. We're going to take it seriously, the comedy will come." The first week of rehearsal was dedicated to understanding the text; this was done at "the table." The complete cast was called for all table work in order to ensure that the company as a whole understood the entirety of the play. This step of the rehearsal process was quite successful in not only ensuring the ensemble understood characters' intentions, objections, actions, and obstacles, but also aided in building relationships amongst the actors themselves. The director made it clear that he had respect for the process and everyone's time commitment. In regards to scheduling rehearsals, he made it understood that no one's time would be wasted; "I consider that a matter of respect," he stated. This approach to rehearsal was especially helpful and encouraging because from the beginning it was apparent that all members of the ensemble were equally valued, a concept which was a fundamental principle of the famous Group Theatre. I believe the element of ensemble acting is essential to a productive rehearsal process.

The next phase of rehearsal consisted of taking the table work to a greater level. Scene by scene the director and actors would dive deeper into the text focusing more specifically on what was going on and what was being said in the individual scene. Scenes were broken down into "bits" or chunks, smaller sections of dialogue, in order to more accurately focus the actor's attention to detail within the scene, this style of working was reinforced in the WVU classroom from day one of my journey to mastering the art of acting. The style is rooted in Stanislavski's system, but it is also supported by Meisner technique. This particular style of working was 
especially helpful for me. I was able to get out of my head and not allow any preconceived ideas or remnants from past performances to invade my current rehearsal process. During this time, I was required to be specific about the language in a way that made me aware of the usefulness of meter, a fact that previously alluded me. A specific example of my new found awareness was a discussion I had with a fellow actor about the use of the word Theseus'. "Perchance till after Theseus' wedding day..." is a line Titania speaks in Act II.I. (Shakespeare 22) I was pronouncing the word with three syllables, but upon scanning the line discovered it is actually pronounced with only two. Prior to my experience in the WVU classroom I had little pedagogical exposure to approaching Shakespearean text. The use of scansion, parentheticals, prose or verse, and the importance of understanding the language were lessons I learned while studying Shakespeare at WVU. These lessons where essential in developing my thesis role. A potential danger of working so concisely on individual scenes was that the actors could lose touch with the ensemble. To avoid separation among the cast the director would assemble them periodically to run through several scenes uniting the actors and reminding them of the different worlds within the play.

During the rehearsal process I started asking myself questions imperative to understanding my characters point of view. How do I feel about mortals? How do I feel about Oberon? How do I feel about my changeling boy? How do I feel about my fairies? In order to answer these questions I combined Uta Hagen's and Stanislavski's techniques addressing imagination. Stanislavski's magic "if" is a great place for any actor to begin their imaginative exploration. I imagined what it would be like to rule the land and create life in nature. I then began to develop a perspective toward mankind, focusing on its mistreatment of nature. 
Images of oil spills, forests leveled, garbage dumps, and other forms of abuse against nature aided in filling me with contempt and disgust for mankind, which I was able to use in performance. Uta Hagen's substitution is another valuable tool to use when developing a connection to a characters point of view. I substituted my own family for Titania's relationships with Oberon, her boy, and her fairies. I recalled disputes between my husband and myself to relate to the fighting among Titania and Oberon. I looked at my fairies and my changeling boy as if they were my children, which allowed for a deep personal need to protect and nurture them. While I was starting to connect to Titania's feelings and point of view, I was finding it difficult to relate to who she really was. Our director admitted that he had no idea what these fairies were "suppose to be", and that made it difficult for the actors, playing fairies, to connect. “I think because our director doesn't have an idea of what the fairies are, we are also unsure. There is a kind of freedom without preconceived ideas, however we are imprisoning our imaginations as a result of this situation. It is a double edged sword. ${ }^{11}$ I was so confused about who Titania was that I started to withdraw. My confusion was exacerbated by a comment made by the director, he described Titania as being a thirteen year old girl who had her first crush, when she was put under Oberon's love spell and fell in love with Bottom. I was torn because my instincts were telling me Titania is a lusty woman and upon falling in love would use her womanly wiles to get her man. I felt that her sex life, prior to that moment, had been nonexistent due to the quarreling between her and Oberon. I felt her desires were reignited by the flower's power and she now had an outlet to unleash her pinned up sexual energy. I strongly believed that Titania was a sexual being who took pleasure in bringing life unto earth

\footnotetext{
${ }^{1}$ Taken from Mya Brown's rehearsal journal.
} 
through the use of her singing, dancing, and love making. This idea is supported by the text. In her first few lines of text speaking of Oberon she states, "I have forsworn his bed and company." (Shakespeare 19) His bed is mentioned first, it holds more weight. The first thing the audience knows of Titania is that when she is angry she withholds sex, and it is as painful for her as it is for Oberon. She describes how horrible an effect these actions, or lack thereof, are having on nature. She even pleads with Oberon to join her now in an uproarious party which will restore balance to nature. Shakespeare uses language to describe how sexual she is: "madly dote" and "She shall pursue it with the soul of love." (Shakespeare 23) I approached our director with my thoughts and to my surprise he completely agreed with me. He admitted that he might have confused me with the note about Titania being a thirteen year old. What he wanted me to get at was the essence of innocence within her. He wanted her to be more than a love sick and lusty woman. I understood that she was multifaceted and while she is certainly a sensual being, she also has an innocence and virtue.

\section{Float vs. Flick}

Voice and movement were essential techniques to address during rehearsals. Due to the nature of the script merging realism with magic and mysticism the possibilities for exploring voice and movement were exponential. The initial impulse of the director for the fairies movements was to embrace animalistic stylized motions. The director suggested that we watch animals in their natural habitat and allow our movements to be inspired by an animal that spoke to our character. "Jerry suggested watching animals and finding one that speaks to me physically. I am excited about this work. It seems like it will be really fun...Off the top of my head I am considering a gazelle, impala, or deer, or maybe a cat, a leopard, jaguar, or 
cheetah." ${ }^{2}$ Although my preliminary impulses drew me to four legged creatures, my work with the movement coach led me to experiment with bird-like characteristics. The first rehearsal that I incorporated these movements was not very successful. The bird-like movement inspired an isolated, jerky neck movement which interfered with my speech. My phrasing became choppy and disconnected and I sounded robotic. The solution was to regulate the movement. I was able to find a power in the movement once I consolidated the motions, and remembered one of Stanislavski's fundamental rules of acting: always move with purpose. The director also assisted in my successfully finding Titania's animalistic stylized movement. During rehearsal, the director told me to be alive within myself and never stop moving. I experimented with the idea and again upon first exploration of the idea it was not successful. The actor portraying Oberon was distracted in the scene and later stated that I looked like I was under water because of my movement. I adjusted the intensity of the movement inside me and it became a subtle and effective device for flowing through the text and the space. I equated the movement to a float versus a flick, in Laban terminology.

\section{Finding My Voice}

During my time in rehearsal and production at WVU I have learned a lot about myself as a performer. I initially took my voice for granted and did not appreciate the importance of vocal warm-ups and preparation. My acting was focused on the "doing", not the tools essential to the doing, and therefore I struggled with consistency in my performances. My greatest vocal challenges included breath support and stressing my vocal apparatus. As an asthmatic I have struggled with breathing for as long as I can remember. I have been hospitalized several times

\footnotetext{
2 Taken from Mya Brown's rehearsal journal.
} 
and resuscitated twice in my lifetime. I am currently on a regiment of medications including steroids which intensify my issues with vocal health, they dry me out considerably. During rehearsal for my role at WVU as Veronica Novak in Yesmina Reza's, God of Carnage, I struggled greatly with my vocal health. I was making big vocal and physical choices that were strenuous on me. I was not warming up properly, and honestly at that time I had no idea the effect misusing my facility would have on me physically, emotionally, and vocally. I was more concerned with honoring the text and the playwright's intentions than I was with maintaining my health. As the rehearsals neared to a close and performances were scheduled to start I began to get sick and lose my voice. I was scared out of my mind. Our vocal coach/voice professor worked one on one with me to help me establish a healthy vocal warm up. She also stressed the importance of meditation, staying hydrated, and resting my voice during recovery. The most important lesson she shared with me during this time was the proper way to use vocal intensity. We discovered the reason I was having difficulty was due to my squeezing and tensing up when I would let out a scream or yell at my husband, which my character did quite a bit. I learned the proper way to approach these vocally intense moments was to open up and release, not tense up, my body, especially all of my articulators; tongue, back of the throat, lips, etc. Once I started using the proper technique during vocally intense moments not only was I able to do it safely but I also connected to those moments on a much more personal and intimate level. I took this knowledge into rehearsal for, A Midsummer Night's Dream. Titania and Veronica are both powerful women who don't hold back their intensity when addressing their husbands, so I was faced with playing yet another role that was vocally challenging. This time, I was prepared to address the vocal dynamics of my role in a healthy way due to my 
previous experience. I was also able to play around with the way I used my voice due to the nature of the character. Our director wanted a deep resonating sound for Titania. In order to provide the sound required I connected as deeply as possible to my groin and diaphragm for support. Pre-rehearsal and pre-show I used a thirty minute warm-up which consisted of yoga, tremoring, humming, tongue twisters, intonating, scales, and connecting to the house of resonance. While I adopted the Laban quality of float for my physical movement, I also used it with my voice. The beautiful verse my character spoke naturally called on a melodic flow of sound, the float helped me organically create that sound.

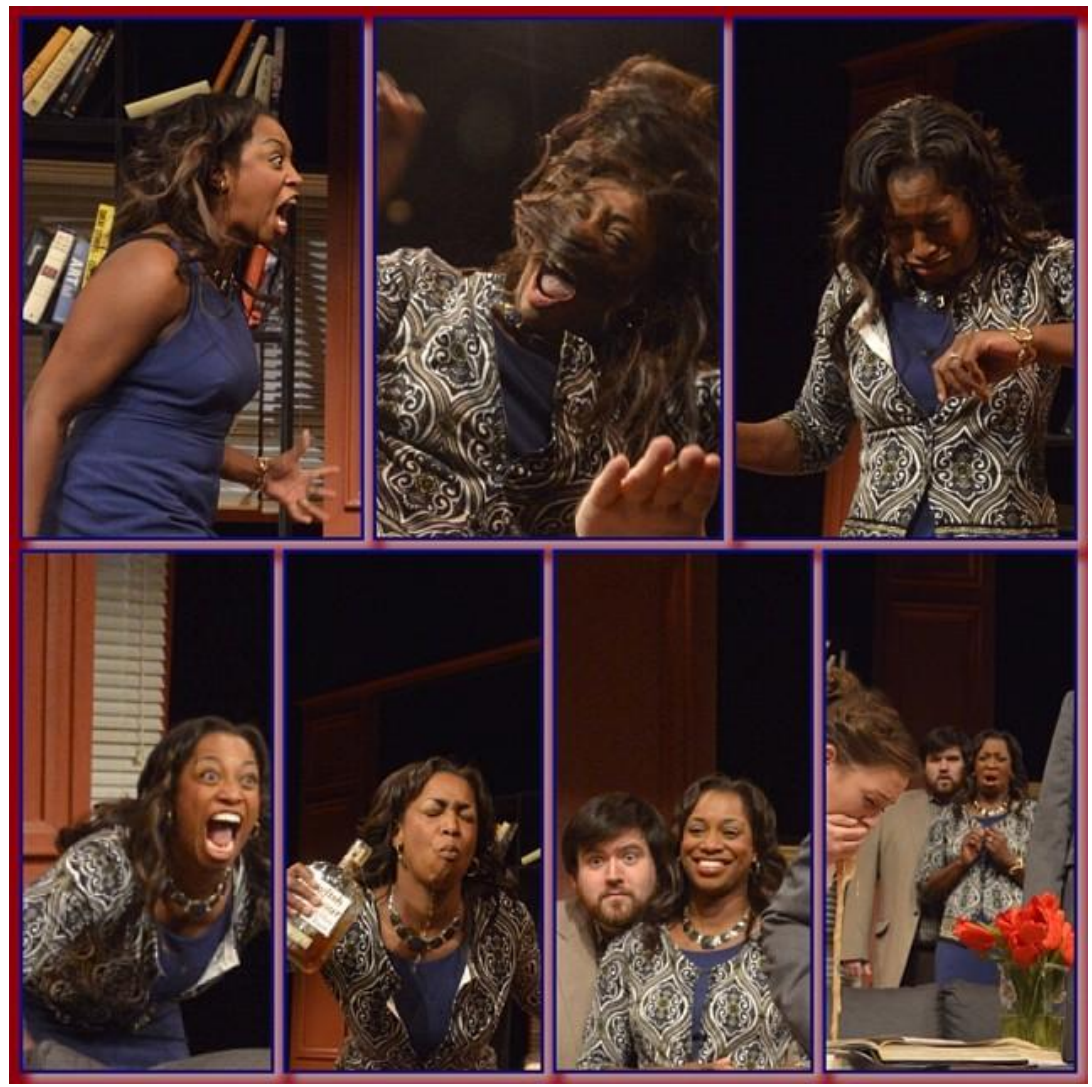

Figure 8 WVU performance of God of Carnage 


\section{Technical Elements}

"Today we had design presentations and the anticipation had me going crazy. My imagination really starts to engage once I am introduced to the visual world of the play. Seeing the set design, lighting design, and costume design sparks something within me." ${ }^{3}$ One's imagination can only take them so far; actually living in the space, feeling and looking at the lights, and wearing the clothes brings a heightened sense of reality to the world of the play.

\section{Let There Be Light}

I was mesmerized by the lighting design. I loved the darkness and rich hues of the forest in contrast to the bright and clean lighting of Athens. Some of my introduction to theatre students, commented on how the forest became darker the further the lovers traveled into it. Shakespeare's ideas of the dangers within the woods were accented by the lighting designer's use of color and intensity. As an African American actor I am always concerned about lighting, especially, when the concept includes darkly lit scenes. I become concerned with the question, "will the audience be able to see me?" Due to the amount of trust I had for the lighting designer I did not have the usual concerns. The designer appeared to have an awareness of his concept and its functionality, and that is why the design was so successful.

\section{Set It Off}

The set design seemed to be simple and carefree. The transitions between locations were fairly uncomplicated and the crew was able to execute scene changes efficiently. Upon seeing the model of the set in rehearsal I thought, "Looks cool and fun." However, once the

\footnotetext{
${ }^{3}$ Taken from Mya Brown's rehearsal journal.
} 
design was realized and we moved into the space I became aware of the difficulties the set presented. The main focus of the design was a tree. The tree was so massive it nearly covered $2 / 3$ of the stage, this left very little room for physical action onstage. The tree sat on a hillside and the ramp used to create the hill was extremely steep. The actors had a difficult time using their blocking in the space so adjustments were made. I always expect an adjustment period when we move from rehearsal space to performance space; but due to the large amount of running, "flying", sleeping, etc. done in the space the transition was

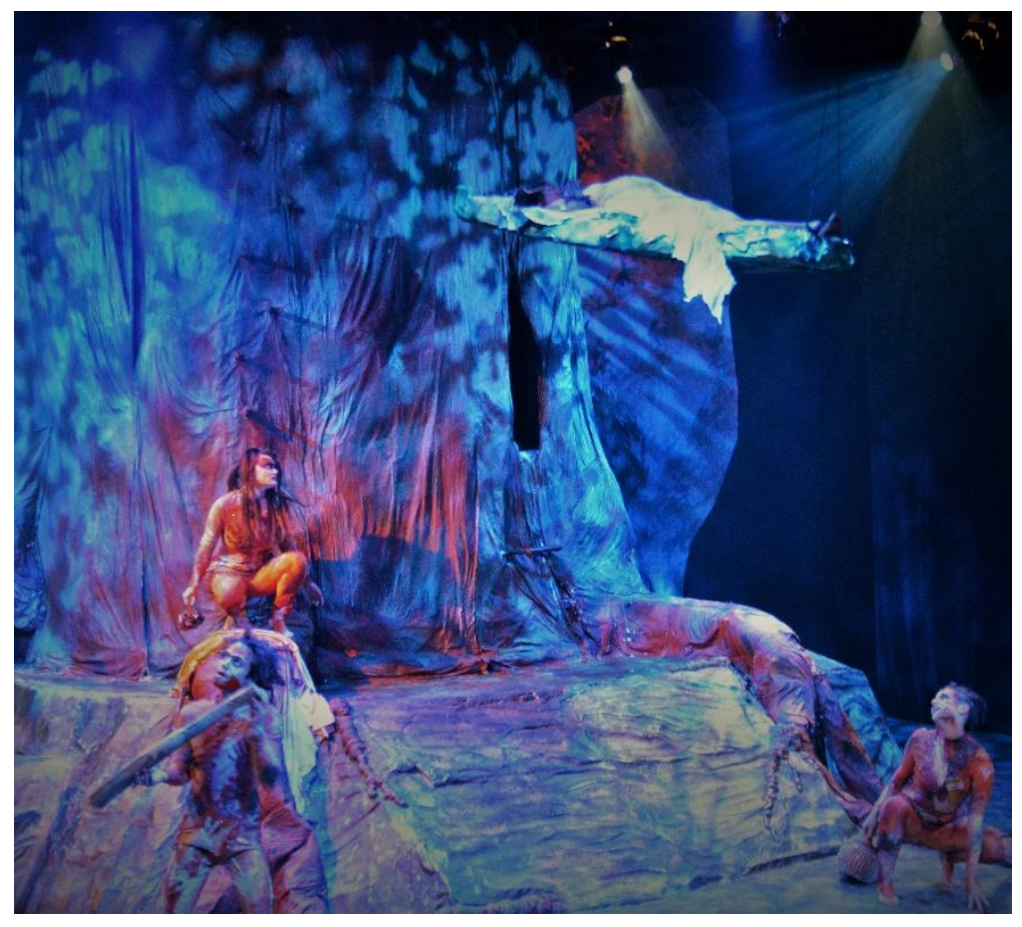

Figure 9 WVU performance Set design \& Lighting design more difficult than usual. I also began to have physical issues due to the set. My character would run and jump off of platforms, and up and down the hillside, and due to the construction of the set these physical movements would create extremely loud noises. To prevent it sounding like an earthquake every time I moved onstage I was cautious with my movements. I realized after the first week of production that the way I was landing on my knee in order to prevent the loud sounds was causing swelling. My knee began to hurt terribly and I actually had to start wearing a brace. Another aspect of the set that took a great deal of adjusting to was Titania's bower. The bower was a coffin shaped bedlike structure which was flown into the air. I was so excited that I was going to be flown in the show; I was bragging to everyone. I had never 
been flown before so I was not aware of the details that go into the process. I was asked my weight, had to wear a crotch intrusive harness, and was in the capable hands of two crew members backstage who were responsible for getting me off the ground and into the air. The initial experience was a bit terrifying. As one might imagine flying a human into the air is not an easy task and we had to work through some difficulties. There were a few occasions when the timing of the flying was too fast causing the bower to swing to and fro as if a gust of hurricane Katrina made its way into the theatre. There was a particular time during a matinee performance when the cables became caught on something in the grid and would not allow my ascension any higher than four feet from the ground; this was an issue because I was not suspended high enough off the ground for the action onstage to continue beneath me. Luckily the actors made adjustments to compensate for my intrusion into their scene; however, in the excitement of the moment as one actor was fleeing the action he accidentally ran into the bower which caused it to swing uncontrollably. I maintained my composure although I nearly wanted to puke. I found it entertaining that during notes after the performance the director commented on how he was running backstage asking the bower operators to just "muscle me up". He also commented that after he saw me swinging in the bower he half expected me to deliver my next line as "What angel wakes me from my flowery...blah (puking noises)". Once all of the kinks were worked out I thought the bower worked beautifully and it was one of the most exhilarating experiences I have had onstage.

\section{We All Wear the Same Shade}

One of my favorite technical aspects of a production is costuming. I believe costumes are gifts for actors, they add to the truthfulness of the play. Movement, voice, and the use of 
set/props is influenced by costumes. For instance when I perform in period pieces the wearing of a corset, shoes, wig, etc. change the way I feel internally not just externally. My initial reaction to the renderings was less enthusiastic than I anticipated. Our costume designer is so extremely talented and she gives a personal touch to her work that is inspiring. However, I was a bit underwhelmed with my costume rendering. In retrospect, I think because I had previous experience with the play and ideas of how my character should look, my reaction was skewed. I was expecting to see light purples and pinks but the colors were browns. I was expecting form fitting but the costume looked bulky. I was expecting to see some sensuality but the rendering looked matronly. It didn't help seeing the renderings for Hippolyta, she looked like everything I wanted to look like: sexy, vivacious, powerful, and captivating. I reflected on my reaction in my journal stating, "I must be honest the rendering of Titania left me feeling disappointed. She wasn't as beautiful and sexy as I imagined she would be. I just keep thinking it will look better on me than on the paper. How horrible of me! I must remain positive. Why does this negative spirit rise in me sometimes? I don't know but my response is what is important. Stay positive!" Looking back on this journal entry makes me ashamed as well as proud. We cannot control our impulse reactions to things but we can control the way we respond. As I started to go to fittings I began to see the vision. Our director wanted to stay away from the stereotypes typically associated with the play and certain elements therein. He specifically requested a setting and costuming that was earthy, a return to nature. So the color palette made sense. There were discussions about the fairies looking like they crawled out of the ground, and I must admit that is certainly what my costume reminded me of, in the best way. I did have a constant issue with my wig. It was a heavy monstrosity that served no purpose other than to weight me down. It 
felt like an extra ten pounds and I was genuinely concerned that the crew would have to add sand to the pulley device that raised my bower in order to compensate for the weight. The idea of the wig was interesting however it did not serve the physical requirements of the play. There was a specific scene when I was laying my head in Bottom's lap and our movement coach had to remind me that action would not be possible with the wig. It was frustrating. Backstage it was an issue as well. because of its width it was hard to get through doorways and past curtains. There were several times that I would try to get onstage in time for my cue and get caught in a curtain or on a costume piece. I honestly felt like a bad joke was being played on me. It never was an easy part of my costume to deal with, but as time went on I became accustomed to it and had a greater awareness of my surroundings because of it. I understand that actors must be flexible, but what is reasonable to ask for the sake of art? And when is functionality being compromised unnecessarily for the art? I also thought the concept of wigging Oberon and Titania with identical wigs was ludicrous. It was embarrassing having intense arguments over our neglect of each other while looking like the "Wonder Twins." I questioned if the audience would take us seriously. It reminded me of one of my favorite parts of theatre; the audience will believe what you tell them to believe. Because we as actors accepted our circumstances as reality the audience did as well. It was a testament to the power of theatre. 


\section{Reflections}

As a result of performing in this play and taking classes at WVU, I have grown immensely as an actor, teacher, and creative artist. I have a greater appreciation and understanding of the amount of sensitivity necessary to create. I have a yearning to contribute to the growth of the craft of acting. And, I accept the responsibility of educating, supporting, and inspiring other young artists.

Some personal changes in my creative process, due to my experiences in this play and throughout my WVU involvements, include: properly warming up physically and vocally; maintaining a healthy facility; exploring movement and voice using Laban, Viewpoints, and Fitzmaurice; and lastly, remaining flexible, respectful, and truthful. I also have a greater desire to explore alternative methods of creating and will embrace thinking outside of the box. I am typically a purist when it comes to plays and performing them. I believe it is an actor's responsibility to honor a playwright's intentions. I look forward to reasonably and responsibly challenging that idea in future works. I also have a greater appreciation and respect for directors and their role in production. As I direct in the future, I will make it a point to maintain an awareness of my actors' emotional, physical, and spiritual health. By maintaining an open and fearless line of communication between my actors and myself I will be able to gauge their progress and stability. I will encourage healthy behaviors. We will warm up as a group and include yoga, breath connection, and tremoring to connect to each other and the text.

As I look back on my time at WVU I will remember loads of fun, challenges completed, personal development, and some heartache. All of my experiences have made me a better person, student, and teacher. I have been an actor for as long as I can remember. I have a vivid 
imagination and I am happiest when I am able to use my talents to tell a story; I am an actor by nature and necessity. In the past three years I have discovered a passion for sharing my experiences and inspiring young artists. I believe it is the responsibility of experienced theatre artists to pass on their knowledge to up and coming artists; it is the only way the craft will survive. I feel it is essential to expose young artists to a healthy way of working. As stated throughout this document, a healthy way of working includes sensitivity to the emotional and physical state of actors. It is necessary to form a foundation of acting based on the fundamentals of the craft: imagination, responding to behavior, and truthful living onstage. I experienced the positive impact this type of work has on young actors while directing a lab theatre production of Diana Son's, Stop Kiss. The actors were able to more fully live truthfully while onstage due to our focus on behavior, and active listening/responding to each other.

In my thesis production, I was able to incorporate my fundamental acting skills to successfully live the role of Titania. I fully used my imagination. I was actively listening and responding to my scene partners. I used substitution to relate to other characters. And finally, I fully respected and trusted my director.

Due to my experiences at WVU I now find great value in teaching others the importance of taking care of their facility (voice, body, and spirit). I have subscribed to the importance of developing a warm up routine involving yoga and tremoring work to prepare myself for productions. The lessons I've learned in acting can be applied to any career field and aid in ones pursuit of self. I believe we never stop learning and through my experiences in the classroom and on stage, I have learned a lot about the art of acting as well as myself. 


\section{Bibliography}

A\&E Television Networks. "William Shakespeare." Bio. 2015. 20 April 2015.

Carson, Shelley H. "Creativity and Psychopathology: A Shared Vulnerability Model." The Canadian Journal of Psychiatry 56 (2011).

Hagen, Uta. Respect for Acting. New York: Macmillian, 1973.

Meisner, Sanford. On Acting. New York: Random House, Inc., 1987.

Merlin, Bella. The Complete Stanislavsky Toolkit. Hollywood: Quite Specific Media Group LTD, 2007.

Shakespeare, William. A Midsummer Night's Dream. Ed. Russ McDonald. New York: Pelican Books, 2000. Print.

Stanislavski, Constantin. An Actor Prepares. Reprint. New York: Routledge, 1989. 